\title{
APLIKASI TEKNOLOGI FERMENTASI LIMBAH SAGU UNTUK MENUNJANG KETERSEDIAAN PAKAN SAPI DI DESA PUPUAN TEGALLALANG GIANYAR BALI
}

\author{
N.G.K. Roni ${ }^{1}$, T.B. Kusmiyarti ${ }^{2}$, N.W. Siti ${ }^{3}$ dan N.K. Karyati ${ }^{4}$
}

\begin{abstract}
ABSTRAK
Kegiatan pengabdian kepada masyarakat ini bertujuan untuk alih teknologi fermentasi untuk pembuatan pakan silase dalam menunjang peternakan sapi Bali perbibitan di Desa Pupuan, Kecamatan Tegallalang, Kabupaten Gianyar. Metode yang diterapkan dalam pemberdayaan masyarakat adalah sebagai berikut: (1) Kordinasi dan komunikasi secara partisipasif dengan kelompok ternak pemelihara sapi perbibitan untuk merumuskan program mulai dari perencanaan, operasional dan evaluasi; (2) Penyuluhan untuk membangun persepsi dan pemahaman masyarakat mengenai inovasi atau program yang diterapkan; (3) Pelatihan dan simulasi mengenai terapan ipeks yang dialihkan bagi masyarakat; (4) Pendampingan yaitu pertemuan secara berkala dan berkelanjutan antara pendamping dengan masyarakat sasaran hingga ipteks yang dialihkan dapat dilaksanakan secara mandiri oleh masyarakat. Hasil yang diperoleh menunjukkan bahwa Kegiatan desiminasi ipteks melalui program IbW di Desa Pupuan, Kecamatan Tegallalang, Kabupaten Gianyar dapat berlangsung dengan baik yang ditunjukkan dengan adanya partisipasi aktif dan daya adopsi ipteks yang tinggi. Partisipasi aktif mitra dalam seluruh kegiatan desiminasi teknologi cukup tinggi, yaitu kehadiran anggota kelompok pada saat penyuluhan dan pelatihan mencapai $100 \%$, yang bertanya/mengemukakan pendapat $60 \%$, dan ikut mencoba praktek 68\%. Kemampuan adopsi ipteks dan inisiatif mitra untuk memproduksi produk secara mandiri cukup tinggi, sebesar $60 \%$.
\end{abstract}

Kata Kunci: Pakan sapi, teknologi fermentasi, silase, limbah sagu.

\begin{abstract}
Community service activities that aim to transferring fermentation technology to make silage feed to support of breeding Balinese cattle in Pupuan Village, Tegallalang District, Gianyar Regency. The methods applied in the community empowerment are as follows: (1) Participatory coordination and communication with livestock breeding groups to formulate programs planning, operation and evaluation; (2) Counseling to build community perceptions and understanding of innovations or programs implemented; (3) Training and simulation of applied ipeks transferred to the community; (4) Assistance is regular and continuous meetings between assistants with target communities to transferred science and technology can be implemented independently by the community. The results show that dissemination activities through IbW program in Pupuan Village, Tegallalang district, Gianyar Regency can take place well indicated by active participation and high adoption of science and technology. The active participation of partners in all technological dissemination activities is quite high, ie the presence of group members at the time of counseling and training reaches $100 \%$, who ask/express opinion $60 \%$, and try to practice $68 \%$. The ability of science and technology adoption and partner initiatives to produce products independently is high enough, at $60 \%$
\end{abstract}

Keywords: Cattle feed, fermentation technology, silage, sago waste.

\footnotetext{
1,3 Fakultas Peternakan,Universitas Udayana, gustironi@unud.ac.id

${ }^{2}$ Staf Pengajar PS Agroekoteknologi Fakultas Pertanian Universitas Udayana, tatihartanto@ymail.com

${ }^{4}$ Staf Pengajar Universitas Dwijendra
} 


\section{PENDAhuluan}

Penggunaan lahan di Desa Kedisan dan Pupuan didominasi oleh lahan pertanian yang mencapai 87 $\%$. Begitu pula dengan mata pencaharian penduduk lebih dari $73 \%$ berasal dari sektor pertanian. Hal ini mengindikasikan bahwa sektor pertanian merupakan bidang startegis sehingga perlu medapatkan prioritas. Sektor peternakan khususnya sapi memegang peranan yang cukup penting sebagai usaha penunjang ekonomi keluarga. Ternak sapi di desa Pupuan dan desa Kedisan merupakan komoditi andalan Kabupaten Gianyar di sub sektor peternakan. Pemerintah Kabupaten Gianyar menjadikan Kecamatan Tegallalang sebagai sentra pengembangan sapi bibit. Salah satu kendala utama peternakan sapi khusunya sapi bibit adalah belum diadopsinya teknologi penyediaan pakan oleh peternak sehingga jumlah sapi yang dipelihara sangat terbatas. Limbah sagu (Gambar 1.1) produksi industri rumah tangga pembuatan tepung sagu (Gambar 1.2) termasuk kategori limbah basah (wet by-products) karena masih mengandung kadar air $70-80 \%$, sehingga dapat rusak dengan cepat apabila tidak segera diproses. Perlakuan melalui pengeringan membutuhkan biaya yang relatif tinggi, sehingga perlu dikembangkan melalui teknologi alternatif lain agar produk tersebut dapat dimanfaatkan secara lebih efisien. Mengatasi hal tersebut perlu dilakukan penyuluhan, pelatihan dan pendampingan terhadap petani peternak agar dapat meningkatkan pengetahuan dan keterampilan tentang budidaya ternak sapi dan penyediaan pakan berkualitas yang tersedia sepanjang tahun.

Hijauan dan limbah pertanian berupa jerami padi merupakan sumber pakan utama, namun ketersedian hijauan terbatas terutama pada musim kemarau dan jerami padi yang hanya tersedia pada musim panen merupakan kendala dalam penyediaan pakan yang cukup dan berkesinambungan. Di sisi lain peternak sangat ingin meningkatkan jumlah sapi yang dipehara, sehingga perlu dicarikan alternatif sumber bahan pakan yang bisa digunakan sebagai stok pakan. Pemanfaatan limbah industri pertanian misalnya limbah sagu yang selama ini biasanya terbuang dan berpotensi mencemari lingkungan, memiliki kelemahan yaitu cepat mengalami kerusakan srhingga perlu sentuhan teknologi untuk mengatasinya.

Pengabdian masyarakat ini bertujuan untuk meningkatkan pengetahuan dan ketrampilan peternak memanfaatkan teknologi fermentasi, meningkatkan pengetahuan dan ketrampilan peternak membuat turunan fermentor dan menghasilkan silase limbah sagu sebagai stok pakan.

\section{METODE PELAKSANAAN}

Metode yang diterapkan dalam pemberdayaan masyarakat adalah sebagai berikut: (1) Penyuluhan untuk membangun persepsi dan pemahaman masyarakat mengenai inovasi atau program yang diterapkan, (2) Pelatihan dan simulasi mengenai terapan ipeks yang dialihkan bagi masyarakat, dan (3) Pendampingan yaitu pertemuan secara berkala dan berkelanjutan antara pendamping dengan masyarakat sasaran hingga ipteks yang dialihkan dapat dilaksanakan secara mandiri oleh masyarakat

\subsection{Tahap Kegiatan}

Pelaksananan kegiatan alih teknologi fermentasi untuk pembuatan silase limbah pertanian untuk menunjang ketersediaan pakan sapi Bali adalah sebagai berikut :

(1) Kordinasi dan komunikasi secara partisipasif dengan masyarakat sasaran untuk merumuskan program mulai dari perencanaan, operasional dan evaluasi 
(2) Penyuluhan tentang pentingnya teknologi budidaya ternak sapi, pemanfaatan limbah untuk pakan dan aplikasi teknologi fermentasi untuk menjamin ketersediaan pakan yang mencukupi kebutuhan.

(3) Pelatihan penggunanaan teknologi fermentasi untuk pembuatan silase limbah pertanian

Pembuatan demplot, pemberian bantuan mesin (Gambar 2.1 dan pendampingan (Gambar 2.2) produksi silase limbah pertanian melalui bimbingan teknis secara berkala terhadap kelompok peternak dan pemberian konsultasi menyangkut solusi dari berbagai persoalan terkait dengan aplikasi teknologi tersebut.

\section{HASIL DAN PEMBAHASAN}

Limbah sagu merupakan salah satu jenis limbah yang didapatkan pada proses pengolahan tepung sagu. Perbandingan tepung dengan ampas yang dihasilkan pada pengolahan tepung sagu adalah sekitar 1:6 (Rumalatu 1981). Kiat (2006) menyatakan bahwa dalam pengolahan empulur sagu diperoleh $18,5 \%$ pati dan $81,5 \%$ berupa ampas. Teknologi silase adalah suatu proses fermentasi, mikroba merubah pakan menjadi meningkat kandungan nutrisinya (protein dan energi) dan disukai ternak karena rasanya relatif manis. Silase merupakan proses mempertahankan kesegaran bahan pakan dengan kandungan bahan kering 30 - $35 \%$ dan proses ensilase ini biasanya dalam silo atau dalam lobang tanah, atau wadah lain yang prinsipnya harus pada kondisi anaerob (hampa udara), agar mikroba anaerob dapat melakukan reaksi fermentasi (Sapienza dan Bolsen, 1993). Keberhasilan pembuatan silase berarti memaksimalkan kandungan nutrien yang dapat diawetkan. Selain bahan kering, kandungan gula bahan juga merupakan faktor penting bagi perkembangan bakteri pembentuk asam laktat selama proses fermentasi (Khan et al., 2004).

Kegiatan ini dilaksanakan di kelompok ternak Pucak Mesari yang beranggotakan 25 orang di desa Pupuan, Tegallalang, Gianyar. Desiminasi teknologi dilaksanakan melalui kegiatan sosialisasi dan persiapan materi, kegiatan penyuluhan dan pelatihan singkat selama 1 hari yang dipusatkan di kandang mitra, serta kegiatan pendampingan melalui pembentukan demoplot di kelompok ternak mitra. Ipteks yang didesiminasikan adalah teknologi produksi pakan silase dengan teknologi fermentasi menggunakan turunan fermentor yang dibuat oleh peternak. Evaluasi kegiatan dilakukan pada setiap sub-kegiatan melalui; 1) Evaluasi tingkat partisivasi mitra, 2) Evaluasi penguasan/daya adopsi Iptek, dan 3) Evaluasi kemampuan membuat produk Ipteks secara mandiri. Bahan baku silase terdiri dari limbah sagu (limbah pembuatan tepung sagu), dedak padi, dan fermentor. Komposisi masing-masing material tersebut disajikan pada Tabel 3.1.

Tabel 3.1. Formula Silase Limbah Sagu yang diproduksi dengan Teknologi Fermentasi

\begin{tabular}{|r|l|c|}
\hline No & Bahan Silase & Jumlah \\
\hline 1 & Limbah Sagu $(\mathrm{kg})$ & 18 \\
\hline 2 & Dedak Padi (kg) & 6 \\
\hline 3 & Fermentor (liter) & 1 \\
\hline & \multicolumn{1}{|c|}{ Total $(\mathrm{kg})$} & 25 \\
\hline & & \\
\hline & Fermentor & Jumlah \\
\hline 1 & Starter (liter) & 1 \\
\hline 2 & Molases/gula (kg) & 1 \\
\hline 3 & Air (liter) & 18 \\
\hline & & \\
\hline
\end{tabular}


Pelaksanaan kegiatan dapat berjalan dengan baik dan dengan peran serta mitra yang cukup tinggi (Tabel 3.2), adapun kegiatan penyuluhan dan pelatihan singkat yang dipusatkan di areal kandang mitra diikuti oleh $100 \%$ anggota mitra dan pada kegiatan tersebut $60 \%$ anggota mitra mengajukan pertanyaan/mengemukakan pendapat terkait produksi ternak sapi bali, penyediaan pakan dan tata cara pemanfaatan limbah untuk pakan. Saat kegiatan pelatihan, 68\% anggota mitra ikut membantu produksi pakan silase. Kegiatan demoplot pelatihan teknologi produksi pakan silase juga dapat berlangsung dengan baik. Produksi produk silase limbah sagu (Gambar 3.1) pada lokasi demoplot bisa dilakukan dalam skala besar karena dalam proses pencampurannya menggunakan mesin bantuan program IbW yaitu bisa memproduksi 1-3 ton tergantung ketersediaan limbah sagu yang diperoleh, sehingga bisa mencukupi kebutuhan pakan untuk 12 ekor sapi selama 1-2 bulan. Pada saat tersebut beberapa anggota kelompok juga memproduksi produk secara mandiri. Berdasarkan hasil pengamatan diketahui $60 \%$ mitra telah mampu memproduksi produk secara mandiri (Tabel 3.2) dengan hasil produk yang palatable/disukai ternak.

Tabel 3.2. Partisipasi Mitra dalam Kegiatan

\begin{tabular}{|c|c|c|c|}
\hline \multirow{2}{*}{ No } & \multirow{2}{*}{ Kegiatan } & \multicolumn{2}{|c|}{ Mitra } \\
\hline & & Jumlah & $\%$ \\
\hline A & Kegiatan Penyuluhan - Pelatihan Singkat & & \\
\hline 1 & Absensi/Kehadiran & 25 & 100 \\
\hline 2 & Mengajukan pertanyaan/pendapat & 15 & 60 \\
\hline 3 & Ikut mencoba & 17 & 68 \\
\hline B & Kegiatan Demoplot & & \\
\hline 1 & Membantu produksi produk (silase limbah sagu) & 20 & 80 \\
\hline 2 & Memproduksi silase secara mandiri & 15 & 60 \\
\hline
\end{tabular}

Kesukaan ternak (Gambar 3.2) terhadap produk yang dihasilkan mitra dan ketahanan (daya simpan) produk yang sampai lebih dari 2 bulan menunjukkan daya adopsi ipteks mitra yang cukup tinggi dan keberhasilan pelaksanaan kegiatan desiminasi teknologi pada mitra. Hal ini kemungkinan disebabkan oleh adanya kemauan dan partisipasi aktif mitra yang tinggi dalam seluruh sub-kegiatan serta adanya kesadaran mitra akan pentingnya teknologi yang didesiminasikan. Disamping itu teknologi yang didesiminasikan merupakan teknologi tepat guna yang relatif murah dan mudah diaplikasikan oleh masyarakat termasuk oleh petani-peternak. Berdasarkan Tabel 3.2 diketahui rataan partisipasi aktif mitra pada seluruh sub kegiatan adalah $72,8 \%$, sedangkan inisiatif untuk memproduksi produk pakan silase adalah sebesar $60 \%$. Tingginya partisipasi dan daya adopsi ipteks mitra juga tercermin dari kesukaan ternak terhadap produk yang dihasilkan dan ketahanan/daya simpannya yang relatif lama yang merupakan salah satu indikasi kualitasnya yang baik.

Keberhasilan adopsi teknologi produksi pakan silase telah memberikan manfaat yang sangat besar bagi mitra karena mitra mengakui sangat terbantu dengan adanya teknologi tersebut khususnya dalam hal penyediaan stok pakan sehingga berani memelihara sapi yang lebih banyak tanpa kawatir kekurangan pakan terutama pada musim kemarau dan kesibukan lain yang menyita waktu lebih banyak. Pemanfaatan limbah sagu sebagai pakan juga memberikan sumber penghasilan tambahan bagi industri rumah tangga pembuat tepung sagu karena sebelumnya banyak limbah sagu yang menumpuk dan akhinya rusak. 


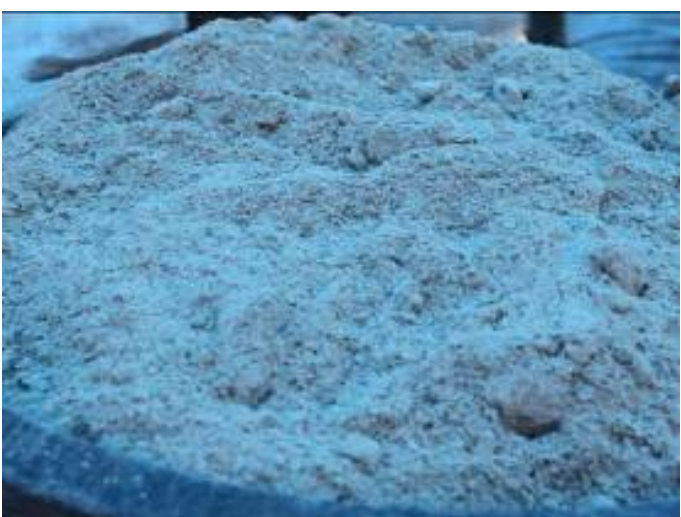

Gambar 1.1. limbah sagu

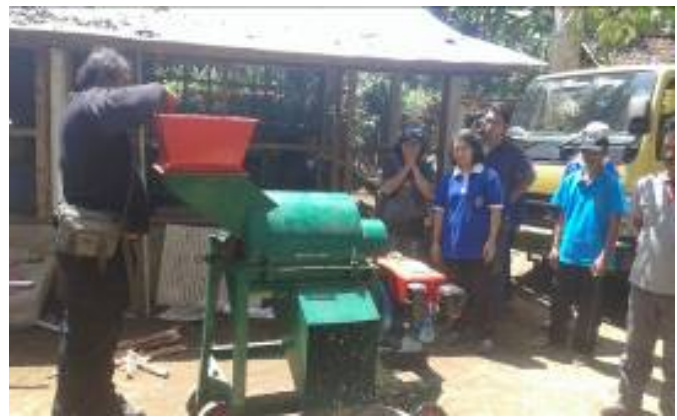

Gambar 2.1 Bantuan mesin pencampur silase
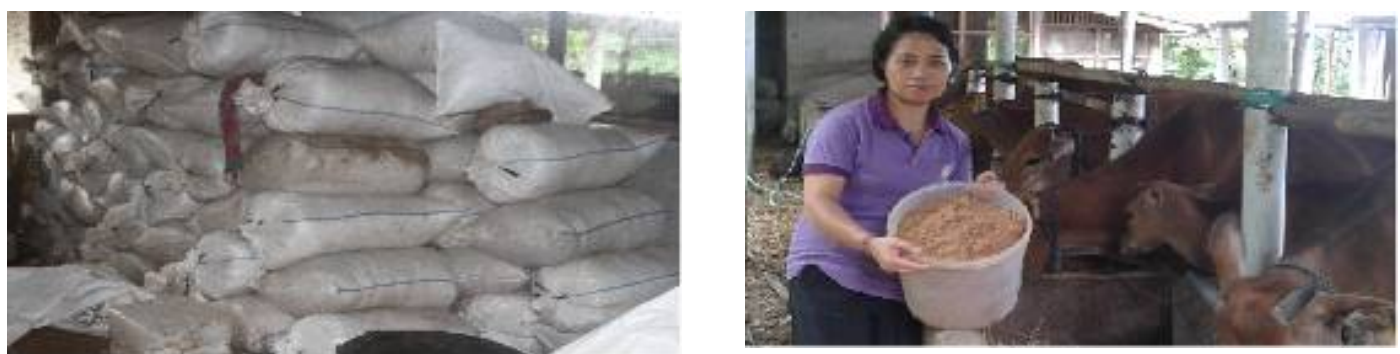

Gambar 3.1 Produk silase limbah sagu
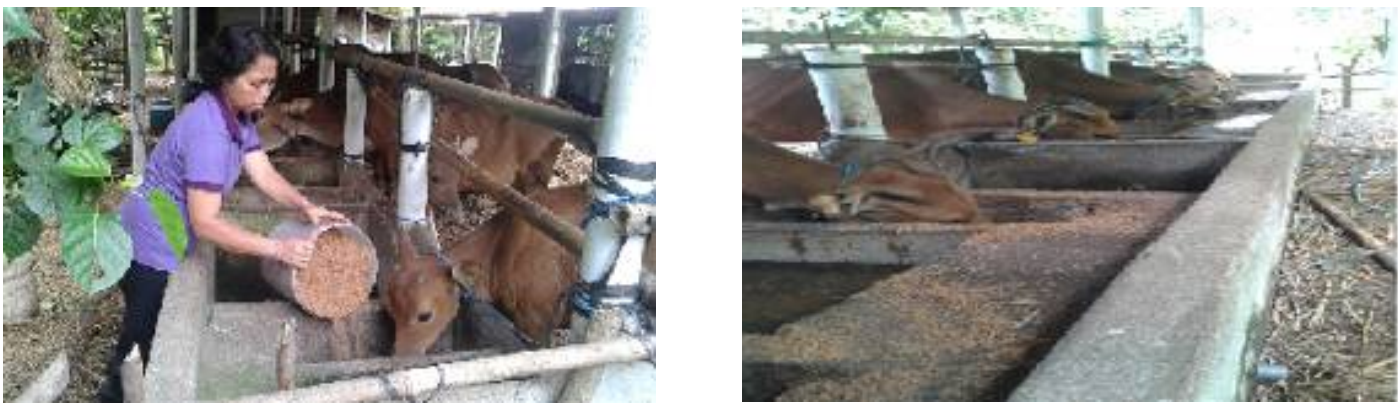

Gambar 3.2 Silase limbah sagu yang disukai oleh sapi 


\section{KESIMPULAN DAN SARAN}

1. Kegiatan desiminasi ipteks dapat berlangsung dengan baik yang ditunjukkan dengan adanya partisipasi aktif dan daya adopsi ipteks yang tinggi.

2. Partisipasi aktif mitra dalam seluruh kegiatan desiminasi teknologi cukup tinggi, yaitu sebesar $72,8 \%$

3. Kemampuan adopsi ipteks dan inisiatif mitra untuk memproduksi produk secara mandiri cukup tinggi, yaitu sebesar $60 \%$.

\section{UCAPAN TERIMAKASIH}

Penulis menyampaikan terima kasih yang sebesar-besarnya kepada Direktorat Riset dan Pengabdian Masyarakat Kemenristek Dikti atas dana yang diberikan, Ketua Lembaga Penelitian dan Pengabdian kepada Masyarakat Universitas Udayana serta kelompok ternak Pucak Mesari yang telah membantu kelancaran kegiatan ini.

\section{DAFTAR PUSTAKA}

Sapienza, D.A. dan K.K. Bolsen. 1993. Teknologi Silase (Penanaman, Pembuatan dan Pemberiannya pada Ternak). Penerjemah: Martoyondo Rini B.S.

Khan, M.A., M. Sarwar and M.M.S. Khan. 2004.Feeding value of urea treated corncobs ensiledwith or without enzose (corn dextrose) for lactating crossbred cows. Asian-Aust. J. Anim. Sci. 8: $1093-$ 1097.

Rumalatu FJ. 1981. Distribusi dan Potensi Pati Beberapa Jenis Sagu Metroxylon sp. di Daerah Seram Barat. Karya Ilmiah Fakultas Pertanian/Kehutanan Unpati yang Berafiliasi dengan Fakultas Peternakan IPB. Bogor (ID)

Kiat LJ. 2006. Preparation and characterization of carboxymethyl sago waste and its hydrogel. [Thesis]. Malaysia (MY): Universitas Putra Malaysia. 